\title{
Profesionalizace vzdělávání učitelů pro primární školu - možnosti a meze
}

\author{
Anna Tomková \\ Univerzita Karlova, Pedagogická fakulta \\ Vladimíra Spilková \\ Univerzita Pardubice, Filozofická fakulta
}

\begin{abstract}
Abstrakt: Cílem přehledové studie je reflektovat snahy o profesionalizaci vzdělávání učitelů primárních škol v České republice. To znamená na základě relevantních teoretických a výzkumných zdrojů posoudit jak silné stránky, tak limity, které se ukázaly při realizaci profesionalizačně zaměřené př́pravy budoucích učitelů, a to $v$ širším kontextu mezinárodních trendů $\checkmark$ této oblasti. Úvodní část příspěvku je věnována proměnám $v$ pojetí profese, měnícím se nárokům na role a klíčové kompetence učitele, na kvalitu vykonávání profese v souvislosti s proměnami školního vzdělávání. Trend k profesionalizaci učitelství je reflektován zejména ve vztahu k učitelství pro primární školu. Jsou prezentovány specifické charakteristiky profese učitele primární školy jako východisko pro koncepci vzdělávání této kategorie učitelů. Těžiště příspěvku spočívá v reflexi kličových charakteristik profesionalizace vzdělávání učitelů primárních škol a možných cest k jejich realizaci. Možnosti a meze uvedených přístupů jsou diskutovány a argumentovány také na základě srovnání s vybranými zahraničními přístupy.
\end{abstract}

Klíčová slova: profesionalizace učitelství, učitel primární školy, profesionalizace vzdělávání učitelů, reflektivní př́istup k vzdělávání učitelů, Boloňská deklarace

\section{Professionalization of Teacher Education for Primary School - Options and Limits}

Abstract: The aim of the review study is to reflect efforts to professionalize the education of primary school teachers in the Czech Republic. This means, on the basis of relevant theoretical and research resources, to assess both the strengths and the limits that have emerged in the realization of the professionally oriented preparation of future teachers in the wider context of international trends in this field. The introductory part of the contribution is devoted to changes in the concept of the profession, the changing demands on the roles and key competences of the teacher, on the quality of performance of the profession in connection with changes in school education. The trend towards professionalisation of teaching is reflected mainly in relation to primary school teaching. Specific characteristics of the primary school teacher's profession are presented as the basis for the concept of education of this category of teachers. The main focus of the paper is to reflect the key characteristics of professionalization of the primary school teachers' education and the possible ways to implement them. The possibilities and limits of these approaches will also be discussed on the basis of the comparison with selected foreign approaches.

Keywords: professionalization of teaching profession, primary school teacher, professionalization of teacher education, reflective approach to the teacher education, Bologna declaration

Cílem přehledové studie je reflektovat snahy o profesionalizaci vzdělávání učitelů primárních škol v České republice. To znamená na základě relevantních teoretických a výzkumných zdrojů posoudit jak silné stránky, tak limity, které se ukázaly při realizaci profesionalizačně zaměřené príipravy budoucích učitelů, a to v širším kontextu 
10 mezinárodních trendů $v$ této oblasti. Důraz na profesionalizaci přípravy budoucích učitelů souvisí s výraznými proměnami v pojetí učitelské profese, v pojetí klíčových profesních kompetencí potřebných $\mathrm{k}$ jejímu kvalitnímu zvládání v kontextu měnících se nároků na vzdělávání. Úvodní část textu se věnuje těmto otázkám.

\section{$1 \mathrm{~K}$ pojetí profesionalizace učitelství a profesionality učitele}

O učitelské profesi (včetně přípravy na ni) lze přemýšlet na základě různých úhlů pohledu - z hlediska jejího historického vývoje, rozmanitých pojetí učitelství v souvislosti s vývojem školy, měnících se společenských očekávání, prípravy na profesi, profesní socializace $v$ prvních letech praxe, celoživotního profesního rozvoje apod. Lze uvažovat o těchto otázkách v mezinárodní perspektivě či s důrazem na domácí kontext.

$S$ ohledem na rozsah textu se $v$ jeho úvodní části omezíme na konstatování, že $v$ celosvětovém měřitku (byt' $v$ různých zemích $v$ odlišné míre) se vlivem měnícího se společenského kontextu a zvyšujících se nároků na kvalitu školního vzdělávání zásadním zpưsobem mění pohled na učitelskou profesi, na socioprofesní role, klíčové profesní kompetence a etické kvality učitelů. Měnící se nároky na kvalitní zvládání učitelské profese vedou k důrazu na profesionalizaci učitelství, na zvýšení profesionality/kvality učitelů.

Ponecháme nyní stranou diskuse nad různými sociologickými př́stupy k chápání profesionalizace učitelství (srov. Hustler \& Intyre, 1996; Korthagen, 2004; Kot'a, 1998, 2010; Píšová et al., 2011; Spilková et al., 2008) a ve zkratce naznačíme pojetí profesionalizace učitelství z hlediska pedagogiky, resp. pedeutologie. Za podstatu profesionalizace považuje řada autorů posílení expertnosti učitelů v procesech vzdělávání a kultivace žákovy osobnosti, která je založena na specifických expertních, profesních znalostech a dovednostech, zejména v pedagogicko-psychologické a oborovědidaktické oblasti.

$\checkmark$ pojetí učitelství jako expertní profese jsou pilírem profesionality učitele profesní vědění, poznatková báze učitelství (knowledge base for teaching), která je vymezena sedmi oblastmi profesních znalostí: znalosti předmětové/oborové, obecně pedagogické (principy a strategie výuky), znalost kurikula (programy, materiály, učebnice), oborovědidaktické znalosti - didaktická znalost obsahu (porozumění obsahu vzdělání a způsoby jeho interpretace žákům), znalost žáků a jejich charakteristik, znalost kontextů vzdělávání (sociokulturní kontexty - rodina, způsob řízení školy, školský systém apod.), znalost cílů, záměrů, klíčových hodnot ve vzdělávání a jejich filozofické a historické zázemí (Shulman, 1987; u nás Janík, 2005; Švec, 2005).

Poznatková báze učitelství je chápána jako základ $\mathrm{k}$ hlubšímu porozumění cílům, obsahu a procesům vzdělávání v širších kontextech, k plánování, realizaci a reflexi výuky a $\mathrm{k}$ sebereflexi $v$ roli učitele. Měla by být také základním východiskem pro koncepci kurikula učitelského vzdělávání. Dalším vlivným přistupem 
ke zkoumání podstaty profesionality učitele je snaha charakterizovat ji prostřednictvím klíčových profesních kompetencí (Helus, 2001; Hustler \& Intyre, 1996; Korthagen, 2004; Lukášová, 2003; Pollard, 2001; Spilková et al., 2004; Švec, 1999; Vašutová, 2004; Weinert, 2001). Existuje řada modelů kompetencí učitele, které se $v$ zahraničí stávají východiskem $\mathrm{k}$ tvorbě profesních standardů. Ty jsou většinou koncipovány jako soubor kompetencí či kvalit učitele, vyjádřených ve vzájemně provázaných znalostech, dovednostech, zkušenostech, postojích a osobnostních předpokladech, které podmiňují kvalitní výkon učitelské profese (Spilková et al., 2010; Vašutová, 2004).

Lze sledovat i jiné přístupy, které například zdůrazňují význam profesní odpovědnosti učitele $v$ nejširším slova smyslu, ve smyslu uvědomění si a přijetí odpovědnosti za zásadní podíl na socializaci žáků, za podporu optimálního rozvoje každého žáka vzhledem $\mathrm{k}$ vývojovým a individuálním možnostem a současně s ohledem na společenské požadavky týkající se kvality vzdělávání. Důležitým předpokladem přijetí takto pojaté profesní odpovědnosti jsou zvnitřněné profesní hodnoty, jimiž se učitel cítí vázán, zdravé profesní sebevědomí, přesvědčení o vlastní profesní zdatnosti (Gavora, 2008), tedy, že jsem schopen pozitivně ovlivňovat vývoj žáků (překonávat negativní vlivy, např. nepř́znivé rodinné prostředí, nižší předpoklady žáka), že mu jako učitel mohu účinně pomoci apod.

Důležitost etické dimenze vyzdvihuje řada autorů v souvislosti s pojetím učitelství jako pomáhající profese s dưrazem na pojetí profese jako služby veřejnosti vyžadující celoživotní zaujetí a oddanost práci. Z pozic humanistické psychologie vyjadřuje Z. Helus základní smysl učitelské profese jako jedné z antropologicky základních služeb člověka člověku (Bravená, 2012; Helus, 2001, 2012; Lukášová, 2015). Klíčem k porozumění významu etické dimenze učitelství může být také tzv. cibulový model (onion model), který popisuje pět vzájemně propojených vrstev učitelovy osobnosti - jednání, kompetence, přesvědčení, identita, poslání ve vztahu k práci i životu obecně (konkretizované dalšími termíny - duchovní a etická dimenze, odevzdanost profesi, vnitřní angažovanost, inspirace $k$ tomu, co a proč dělám, apod.). Hloubková struktura, vnitřní úrovně - poslání a identita - jsou považovány za zásadní, nebot' podstatně ovlivňují, jak učitel funguje na vnějších úrovních, jak k žákům přistupuje, jak s nimi komunikuje, jak jedná v konkrétních situacích apod. (Kelchtermans \& Ballet, 2002; Spilková et al., 2008)

Závěrem této části zmiňme ještě jeden znak profesionality učitele, který je řadou zahraničních i domácích autorů považován za klíčový, a tím je kompetence, schopnost reflexe a sebereflexe (Janík et al., 2013; Korthagen et al., 2011; Lukášová, 2015; Lukášová-Kantorková, 2002; Nezvalová, 1994; Píšová, 2005; Pollard, 2001; Schön, 1983; Slavík, 2001; Spilková et al., 2004, 2015; Švec, 2000). Důležitost kompetence učitele k reflexi a sebereflexi (bývá nazývána kompetencí k profesnímu růstu) je vyjádřena také tím, že je důležitou součástí profesních standardů ve většině vyspělých zemí. Učitel řeší komplexní situace, setkává se s řadou jevů a nespecifických problémů, ve kterých nejsou vždy zcela jasné př́čina a následek, pro které neexistuje jediné správné řešení, často musí reagovat okamžitě, improvizovat, 
12 zvládat své emoce apod. Náročnost činnosti učitele se zvyšuje nutností reagovat bez odstupu, bez možnosti hlubšího promyšlení.

Sebereflexe učitele je př́ležitostí se v klidu, z odstupu, hlouběji myšlenkově vracet ke své výuce $v$ širších kontextech svých profesních hodnot a přesvědčení, záměrů, cílů, představ a očekávání. Učitel má možnost se znovu vrátit a lépe porozumět také svým pocitům, co a proč prožíval, s jakými důsledky apod. Reflektivní učitel chce nejenom lépe porozumět podstatě své práce a jejím výsledkům, hledat príčiny a souvislosti, ale také shromažd'uje doklady a důkazy o účinnosti svých pedagogických postupů na žáky. Považuje také za důležité přemýšlet o tom, čemu se potřebuje sám dál učit, aby byl dobrým/lepším učitelem. V reflektivním pojetí učitelství a učitelského vzdělávání je „reflektivita chápána jako trvalý princip učitelské profesionality“ (Tomková, 2018, s. 13).

Velmi účinnou cestou ke zkvalitňování práce je sdílení reflektovaných zkušeností s kolegy ve škole či mimo školu (sdílení příkladů dobré praxe $v$ rámci různých profesních komunit apod.). Jak zdůrazňuje T. Janík, pokud je praktická zkušenost nereflektovaná a nesdílená v profesním diskurzu a ztrácí se $v$ podvědomí, pak učitel mezi třídou a sborovnou přichází o největší poklad, o rodinné stříbro profese - a tím je moudrost praxe. Mnohé z výše uvedeného platí i pro další profese. Lze zobecnit, že reflexe a sebereflexe mají klíčový význam pro celoživotní profesní růst i v jiných pomáhajících profesích.

\section{Specifické charakteristiky profese učitele primární školy}

V předcházejícím textu jsme se pokusili naznačit šiři a rozmanitost př́stupů k vymezování podstaty profesionalizace učitelství a klíčových znaků profesionality učitelů. Nyní se zaměříme na učitelství pro primární školu s cílem reflektovat specifické charakteristiky profese učitele primární školy, které jsou jedním ze základních východisek pro koncepci vzdělávání této kategorie učitelů.

Existují nějaké specifické charakteristiky této profesní subkategorie učitelů? Jsou zde nějaké výrazné odlišnosti v pojetí profese a v nárocích na kompetence? Pojetí profese učitele primární školy prošlo zajímavým vývojem. Od akcentu na řemeslné pojetí, přes vlastenecký ráz a kulturní úlohu v národním obrození s vlastní literární a hudební produkcí až $\mathrm{k}$ pokusnictví a didaktické tvořivosti v rámci českého reformního hnutí, přičemž tradiční didaktická a metodická kvalita této kategorie učitelů si zachovala kontinuitu do současnosti (Spilková, 1997; Spilková et al., 2004; Tuček, 1994). V souvislosti s tzv. novou koncepcí primární školy se od sedmdesátých let minulého století zvýšily nároky na oborové znalosti této kategorie učitelů. Na základě požadavků a předpokládaných činností učitele byl stanoven profil učitele primární školy, tedy 1 . stupně základní školy v podobě profilu absolventa odpovídajícího typu studia učitelství (Kořínek, 1981). 
Přestože řada požadavků směrem k učiteli primární školy je identických s nároky na jiné kategorie učitelů, existují nároky specifické (Spilková, 1998). Jedním z nejvýraznějších specifik učitelství pro primární školu je systém jednoho učitele ve tř́dě, $\checkmark$ níž zpravidla vyučuje všem předmětům nebo jejich většině. To s sebou nese specifický úkol pro učitele - zvládnout na určité úrovni obsahovou šíri daných předmětů. Objevuje se také požadavek na integraci obsahu vzdělání, na překračování hranic a hledání styčných bodů mezi různými obory s cílem snažit se zprostředkovávat základy celistvého obrazu světa, který odpovídá globalizačnímu charakteru vnímání a myšlení dětí $v$ tomto věkovém období.

Skutečnost, že učitel primární školy pracuje s dětmi téměř stále sám (oproti týmovému charakteru práce učitele na vyšších stupních) a jeho př́padný negativní vliv nelze kompenzovat působením jiných učitelů, s sebou nese nárok na výrazně zvýšenou odpovědnost za žáky a jejich rozvoj. $V$ současné době se $v$ kontextu společného vzdělávání a důrazu na inkluzi objevují nové nároky na spolupráci učitele primární školy s asistenty pedagoga, speciálním pedagogem, školním psychologem, poradenskými centry apod.

Vzhledem $\mathrm{k}$ závažnosti působení učitele primární školy s dítětem $v$ tak citlivém věku, $\mathrm{k}$ významu položení kvalitních základů vzdělanosti pro další školní a životní dráhu dítěte se tak dostávají do popředí požadavky nejen na pedagogickou erudici a didaktickou zdatnost, ale také nároky na osobnostní kvality učitele. Slovy jednoho z bývalých ministrů školství P. Pit’hy je „učitel obecné školy jediným učitelem, který má dodnes charakter mistra, který svého žáka - učně uvádí do veškerého poznání a který ho celkově osobnostně a postojově formuje. Předává moudrost, kterou sám má, je př́kladem vším, čím sám je a žije...“ (Pit'ha \& Helus, 1993, s. 32).

Vedle obecně lidských kvalit (zejména etická úroveň a ustálený systém hodnot, sociální zralost apod.) je důležitá kultivovanost mluveného projevu, nebot' učitel primární školy má významnou roli ve vytváření jazykové kultury žáků, je pro ně mluvním vzorem. Zdůrazňována je také všeobecná vzdělanost zejména $v$ oblasti národní kultury (české dějiny, literární, výtvarné, hudební, divadelní, filmové umění apod.) a jisté filozofické zázemí. Nechme zde zaznít slova T. G. Masaryka, která pronesl na 1. celostátním sjezdu učitelů ČSR v roce 1920 . V rámci boje za vysokoškolské vzdělání učitelů požaduje, aby $i$

učitel v první třídě měl ucelené vysokoškolské filozofické vzdělání. I když nebude filozofii učit, má filozofem být, aby byl moudrý, nezjednodušoval problémy, neuchyloval se $k$ demagogii, měl širokou škálu fantazie a citlivě reagoval na jemné předivo utváření lidské osobnosti... (Funda, 1995, s. 2)

Také obecný požadavek na zdatnost $v$ oblasti sociálně vztahové je u učitele primární školy zvýrazněn vzhledem k věkovým zvláštnostem dětí, se kterými pracuje. Děti $v$ tomto věku jsou často na učitele silně vázány, představuje pro ně jeden z významných identifikačních vzorů a významnou autoritu, která ještě není př́liš narušována teprve se vytvářejícími vrstevnickými vztahy. Učitel tvoří celkové sociální klima ve třídě, ovlivňuje strukturu žákovských vztahů, učí je vzájemné komunikaci 
14 a společnému soužití ve škole. Zásadním způsobem se podílí na socializaci žáků s důsledky pro jejich sociální rozvoj v dalších letech.

Specifické nároky jsou na učitele primární školy kladeny $v$ oblasti komunikace $s$ rodiči, nebot' vzhledem $k$ nediferencované populaci žáků potřebuje umět jednat $s$ rodiči ze všech sociálních vrstev a vzdělanostních úrovní. Pozitivem je poměrně vstřícný postoj rodičů ke škole na počátku školní docházky dítěte založený na pozitivním očekávání, většinou ještě nezatiženém negativními zkušenosti. Rodiče dětí tohoto věku se zpravidla zajímají o pokroky svého dítěte, mívají důvěru v učitele a jeho práci. Na základě společného zájmu o úspěšný vývoj dítěte může učitel citlivým a kompetentním přístupem získat rodiče ke spolupráci (Rabušicová \& Pol, 1996; Štech, 2004a; Štech \& Viktorová, 2001).

U učitelů primární školy jsou také kladeny zvýšené nároky na diagnostickou činnost, nebot' pracuje s integrovanou a velmi různorodou populací, na jejíž základní diferenciaci se podílí. Po předběžném diagnostickém posouzení navrhuje další kroky, jak u žáků se specifickými vzdělávacími potřebami a problémy nejrůznějšího druhu, tak u dětí s výrazným nadáním v určité oblasti. Také způsob hodnocení žáků v primární škole (širší uplatnění kvalitativního, formativního hodnocení) zvyšuje požadavky na diagnostickou zdatnost učitelů.

Specifické nároky na učitele primární školy (které vyplývají především ze specifik práce s danou věkovou skupinou žáků) jsou ještě zvýrazněny vlivem proměn vzdělávání, učitelské profese a př́pravy na ni po roce 1989 . V oblasti primárního vzdělávání došlo k zásadním změnám - prosazuje se na dítě orientované, osobnostně rozvíjející pojetí primárního vzdělávání, pojetí školy jako služby dítěti, jako pomoci v jeho rozvoji, jako místa, kde jsou vytvářeny příležitosti $k$ všestranné kultivaci dětské osobnosti a k rozvíjení potencialit, které v každém dítěti jsou. Primární pedagogika se přihlásila k principům humanistické psychologie, slovy $Z$. Heluse $k$ pedocentrismu nové generace, jako základnímu východisku pro směřování výuky $z$ hlediska hodnot.

Nový koncept primárního vzdělávání implikuje změny $v$ pojetí profese, rolí a klíčových profesních kompetencí učitele primární školy. U této subprofesní kategorie jsou změny nejvýraznější, lze dokonce hovořit o změně paradigmatu, který je většinově sdílen $v$ profesní komunitě a postupně se prosazuje $v$ praxi primárních škol i v praxi vzdělávání této kategorie učitelů (Horká \& Kratochvílová, 2008; Lukášová, 2003, 2015; Nelešovská et al., 1995; Spilková et al., 2005; Spilková \& Hejlová, 1999, 2010; Tomková, 2018).

V učitelství pro primární školu se vůdčím principem stává důraz na profesionalizaci, který souvisí s širíi působnosti učitele a jeho zvýšenou profesní odpovědností za žáky, za identifikaci a rozvíjení jejich vývojových a individuálních možností, za výsledky učení v nejširším slova smyslu. Pojetí učitele primární školy jako odborníka, který je erudovaným facilitátorem žákova vývoje s cílem dotáhnout každého žáka $k$ jeho osobnímu maximu, jenž umí vytvářet kvalitní vzdělávací situace $k$ úspěšnému kognitivnímu i sociálně emocionálnímu učení u všech žáků, vyžaduje výrazný posun v pojetí kompetencí učitele potřebných ke kvalitnímu zvládání profese. 
V těchto kontextech spočívá těžiště profesní zpưsobilosti učitele primární školy v pedagogické a psychodidaktické kompetenci (Spilková, 1997, 1998; Spilková et al., 2004; Spilková \& Hejlová, 2010). V celku pedagogicko-psychologických kompetencí jsou výrazné zejména nároky na diagnostickou kompetenci propojenou se schopností účinných intervencí (aktuálně také vzhledem k důrazu na inkluzi). Dále kompetence $\checkmark$ oblasti sociálně vztahové, zejména komunikativní, a to jak ve vztahu $k$ žákům, tak ke světu dospělých (rodiče, kolegové, sociální partneři školy apod.). Rủst pedagogické autonomie (u učitele primární školy je výrazným rysem) přináší nároky na schopnost učitele prezentovat, vysvětlovat a zdůvodňovat své pojetí práce.

Za velmi důležitou je považována kompetence $\mathrm{k}$ reflexi praktických zkušeností a sebereflexi $v$ roli učitele. Dovednost přemýšlet nad svou prací, kriticky ji analyzovat ve vztahu k zamýšleným cílům, dosahovaným výsledkům i širším kontextům výuky, umění vyvodit důsledky a následně měnit strategie lze považovat za určitý imperativ pro práci učitele primární školy. A to především v souvislosti s šírí pưsobnosti učitele, se závažností působení na žáky ve vývojově velmi citlivém období a s celkově zvýšenou profesní odpovědností učitele, o nichž byla řeč v předcházejícím textu.

Zásadní úlohu $\mathrm{v}$ profesionalitě učitele primární školy, $v$ jeho způsobilosti dostát současným nárokům na kvalitu vykonávání profese, má psychodidaktická kompetence. Její těžiště spočívá v didaktické transformaci vzdělávacího obsahu pro děti mladšího školního věku, tedy $v$ umění zprostředkovávat obory, oblasti vzdělávání s ohledem na věková specifika, zejména s respektem ke specifice poznávacích procesů, i s ohledem na individuální potřeby a možnosti žáků. Psychodidaktickou kompetenci lze také chápat jako „umění překladu“ z jazyka oboru (odborné pojmy) do jazyka dítěte (prekoncepty) a naopak. Učitel je schopen konfrontovat a propojovat žákưv jazyk a jeho pojmový svět v určité vzdělávací oblasti s oborovými koncepty a se svým pojetím učiva (Štech, 2004b).

Výrazně odlišné je pojetí oborové, předmětové kompetence učitelů primární školy. Vyplývá to z její multidisciplinárnosti založené na didaktickém systému jednoho učitele a šíri vyučovacích předmětů, které musí obsáhnout. Odborně předmětová kompetence této kategorie učitelů je charakterizována mnohostranností jazykového, literárního, vlastivědného, matematicko-přírodovědného a múzického vzdělání, které zahrnuje i tělesnou kulturu (Spilková, 1997; Tuček, 1994). V této šíri dominuje jazyková oblast. Př́rodovědná a vlastivědná erudice je založena především na kompetencích $v$ didaktické transformaci tohoto učiva.

$\mathrm{Na}$ závěr textu o specifikách učitelství pro primární školu, o proměnách $v$ pojetí rolí a klíčových profesních kompetencí u této kategorie učitelů vyjadřujeme přesvědčení, že je důležité formulovat také jádrové hodnoty profese učitele primární školy. Za výrazné impulzy a inspirace $v$ této oblasti považujeme práce, které zdůrazňují hodnoty lidství, lidskosti a duchovní dimenze učitelství (Bravená, 2012; Hejlová, 2010; Helus, 2009, 2012; Lukášová, 2003, 2015). 
Důraz na profesionalizaci učitelství pro primární školu se stal vůdčí ideou pro zásadní transformaci vzdělávání této kategorie učitelů v první polovině devadesátých let minulého století na většině pedagogických fakult $v$ ČR. Konkrétním projevem byla více či méně výrazná změna v proporcích mezi jednotlivými dimenzemi studijních programů. Těžiště studia se přeneslo od dominující oborové, předmětové př́pravy k pedagogicko-psychologické a oborovědidaktické př́pravě včetně praxí a k osobnostně kultivační složce studia. Oborová př́prava je redukována, resp. transformována do základů pro oborovědidaktickou přípravu, která je prioritou. Zde je výrazný rozdíl ve srovnánís koncepcí přípravy učitelů pro vyšší vzdělávací stupně, kde k podobnému vývoji nedošlo.

Změna $v$ obsahových akcentech $v$ kurikulu vzdělávání učitelů primárních škol predstavuje radikální zásah do tradice, kdy v průběhu několika desetiletí dominovalo pojetí O. Chlupa zdůrazňující oborovou přípravu (Váňová, 1995). Důraz na profesionalizaci vzdělávání učitelů primárních škol navázal na koncept V. Př́ihody, který prosazoval, aby se pojetí učitele jako vědeckého pracovníka $v$ pedagogicko-psychologických oborech promítlo do koncepce prípravy na profesi. Změny v kurikulu prípravy této kategorie učitelů, v proporcích mezi jednotlivými složkami studia a zejména míra důrazu na profesní vzdělávání je však také předmětem kritiky některých současných autorů. Upozorňují na rizika spojená s podceňováním oborových znalostí, která mohou u žáků vést $\mathrm{k}$ miskoncepcím a komplikovat založení kvalitních základů pro další poznání v jednotlivých oborech (např. Dvořák et al., 2010).

Šiře profilu učitele primární školy, nutnost zvládat velké množství velmi různorodých oborů a vzdělávacích oblastí pochopitelně neumožňují jít při pregraduálním studiu do hloubky oborových znalostí. Oborová př́prava včetně oborovědidaktické disponuje však dle platného standardu pro regulovanou profesi sumou $50-55 \%$ kreditů. Je naléhavým úkolem odborníků $v$ této oblasti kvalitně využít tento prostor, vymezit nepominutelné obsahy a jádrové znalosti v daných oborech.

Pro profesionalizaci vzdělávání této kategorie učitelů mělo zásadní význam konstituování primární pedagogiky jako svébytného, výrazně antropologicky orientovaného oboru, který se kriticky vymezil vưči tradiční, tzv. bezdětné pedagogice. Od prvních kroků v jeho konstituování v českém kontextu na začátku devadesátých let se podařilo přejít $k$ jeho hlubšímu propracování do podoby ucelenějšího systému, který s oporou o teoretické, komparativní, historické, empirické a experimentální přistupy komplexně řeší otázky výchovy a vzdělávání dětí mladšího školního věku $\mathrm{s}$ ohledem na ontogenetické zvláštnosti tohoto věkového období. $\mathrm{K}$ rozvoji oboru a získání jeho prestiže $v$ rámci pedagogicko-psychologických disciplín přispěly zejména monografické studie a dobře koncipované výzkumy (např. Havlínová, 2016; Hejlová et al., 2013; Helus, 1999, 2009; Horká et al., 2015; Hošpesová, 2016; Kolláriková \& Pupala, 2001; Lukášová, 2003, 2010; Lukavská, 2003; Nelešovská et al., 1995; Spilková, 1997; Spilková, 2005; Švrčková, 2011; Wildová, 2005).

Primární pedagogika se postupně stala základním profilujícím oborem studia, prostorem pro hledání souvislostí a propojování mnoha dosud spíše separovaných 
oborů do smysluplného celku. Šlo také o hledání průniků a styčných bodů ke spolupráci s vývojovou a pedagogickou psychologií, oborovými didaktikami, filozofií výchovy (pochopení soudobého dětství a pojetí dítěte $v$ současných společenských podmínkách), speciální pedagogikou. Idea profesionalizace a její propracování do podoby koncepce studia učitelství pro primární školu pak sehrála důležitou roli při obhajování univerzitního magisterského studia pro tuto kategorii učitelů, které bylo $v$ průběhu posledních dvou desetiletí opakovaně zpochybňováno. Hlavním argumentem bylo, že $v$ profesionalizaci vzdělávání učitelů primárních škol, tedy $v$ důrazu na pedagogicko-psychologickou a oborovědidaktickou př́pravu, je legitimován požadavek na plnohodnotné univerzitní vzdělání. Specifičnost koncepce vzdělávání učitelů pro primární školy byla oficiálně uznána při diskusích o vhodnosti zavedení strukturovaného studia u různých studijních oborů v souvislosti s Boloňskou deklarací (Mareš \& Beneš, 2013; Spilková et al., 2004).

$Z$ učitelských oborů odolalo politickému tlaku na strukturaci studia jen učitelství pro primární vzdělávání. Hlavním argumentem byla výrazná specifika vzdělávání této kategorie učitelů spočívající v důrazu na profesionalizaci a na potřebu integrace, která vyplývá z širokého profilu a multidisciplinarity studia. Odlišné pojetí profesní i oborové složky prípravy vyžaduje model studia, který umožňuje průběžnou interakci mezi jednotlivými prvky kurikula v rámci uceleného studia (které nelze smysluplně rozdělit na dvě části) a dlouhodobý výcvik některých profesních dovedností. Na těchto argumentech byl založen legitimní nárok na výjimku. $V$ průběhu následujících let se prokázalo, jaké príležitosti přináší prostor pěti let pro kvalitu prípravy budoucích učitelů, pro podporu individualizovaného procesu profesního zrání, pro kontinuální gradaci jejich profesního rozvoje (Spilková et al., 2004; Spilková \& Hejlová, 2010).

\section{Klíčové charakteristiky profesionalizace vzdělávání učitelů primárních škol}

Nově vyzdvižené dominanty př́pravného vzdělávání učitelů pro primární školy, tj. pedagogicko-psychologickou a oborovědidaktickou př́pravu včetně praxí a osobnostně kultivační složky studia (Spilková et al., 2004, 2008; Spilková \& Hejlová, 2010), můžeme považovat za klíčové charakteristiky profesionalizačně zaměřeného vzdělávání učitelů. Dominanty formulované v. Spilkovou korespondují také s uvažováním zahraničních odborníků, kteří rovněž hledají jasné vyjádření nutné zásadní změny v př́stupu k vysokoškolskému vzdělávání učitelů. Např́íklad Perrenoud (2001) vyzdvihuje, že jde o to, vytvářet dobré podmínky pro proces individuální nebo skupinové proměny, který umožňuje stát se profesionálem, tím, kdo umí v dané profesi samostatně, odpovědně a tvořivě jednat.

Dominanty a zároveň specifika vzdělávání učitelů pro primární školy byly $v$ ČR vyjádřeny také v Rámcové koncepci prípravného vzdělávání učitelů primárních škol $\checkmark$ ČR (2015). Autoři rámcové koncepce doporučili koncipovat studium jako pětileté nestrukturované magisterské studium a nově nahlédnout významnost jednotlivých 
18 složek studijního programu. Zdůraznili nutné provázání oborové a oborovědidaktické složky, význam pedagogicko-psychologické složky a reflektivního pojetí praxí (Stuchlíková \& Janík, 2017, s. 264).

Rámcové požadavky na studijní programy, jejichž absolvováním se získává odborná kvalifikace $k$ výkonu regulovaných povolání pedagogických pracovníků, upřesnily $\checkmark$ roce 2017 procentuální zastoupení složek př́pravy učitelů primárních škol. ${ }^{1}$ Cílem pokračující odborné diskuse by měla být harmonizace složek a jejich propojování ve prospěch posilování učitelské prípravy, aby se absolventi cítili být učiteli, chtěli vykonávat profesi a dále se vzdělávat, byli si jisti v klíčových rolích a v profesních činnostech. V př́pravě učitelů primárních škol je $v$ ČR dlouhodobě rozvíjen a monitorován reflektivní př́stup ke vzdělávání učitelů (např. Janík et al., 2013; Lukášová, 2015; Pí̌̌ová et al., 2011; Spilková, 2016; Spilková et al., 2010; Spilková \& Hejlová, 2010; Švec, 2009; Švec et al., 2014). Reflektivní př́stup lze považovat za svorník mezi akademickým a socioprofesním/kompetenčním pojetím vysokoškolského vzdělávání.

Teoretickými východisky reflektivního př́stupu ve vzdělávání učitelů jsou teorie vzdělávání zaměřeného na studenta a jeho učení (Barr \& Tagg, 1995; Korthagen et al., 2011; Lukášová-Kantorková, 2002; Píšová, 2005; Pí̌ová et al., 2011). Je definováno prostředí podporující profesní učení a získávání profesních znalostí, založené na aktivním učení studentů, spolupráci, individualizaci, modelování, formativním hodnocení, reflexi (Hoidn, 2016).

\subsection{Cíle a obsahy profesionalizačně zaměřeného vzdělávání učitelů primárních škol}

Také v profesionalizačně pojatém vzdělávání učitelů dominují mezi vzdělávacími cíli profesní znalosti. Je očekáváno, že absolventi profesní znalosti dovedou využít při řešení komplexních pedagogických a didaktických situací v pedagogické praxi. Specifikou nutné profesní znalostní výbavy absolventů učitelství pro primární školy je značná šíře očekávaných profesních znalostí. Profesionalizačně zaměřené vzdělávání učitelů vymezuje také očekávané profesní činnosti, které předpokládají šíři porozuměných profesních znalostí: pedagogickou komunikaci a budování podnětného a bezpečného prostředí, plánování, řízení a reflektování učení žáků, hodnocení učení a výsledků učení žáků, komunikaci s dalšími aktéry vzdělávání žákủ a profesní seberozvoj (např. Tomková et al., 2012). Ve výčtu profesních kompetencí absolventů učitelství pro primární školy odborníci zdůrazňují především kompetence orientované na žáka a jeho učení, kompetence orientované na vzdělávání a výuku (edukaci) a kompetence orientované na seberozvoj učitele (Lukášová, Svatoš, \& Majerčíková, 2014). Profesionalizačně zaměřené vzdělávání učitelů cíleně rozvíjí profesní identitu studentů, tedy vědomí sebe sama v učitelské profesi (Kratochvílová, Horká, \& Chaloupková, 2015; Lukášová, 2015; Pravdová, 2014; Spilková, 2011).

1 Pedagogicko-psychologická príprava (učitelská propedeutika) 26-32\%, oborová a oborovědidaktická složka 50-55\%, reflektovaná pedagogická praxe 10-15\% a zpracování diplomové práce 5-10\% (Rámcové požadavky..., 2017). 
Šíre vzdělávacích obsahů a nové akcenty na oborovědidaktickou, pedagogickopsychologickou a praktickou složku vzdělávání učitelů pro primární školy znovu otevírá otázky spojené s nutným výběrem a aktualizací klíčových profesních znalostí a dovedností studentů. Tito studenti studují v ČR i v zahraničí podle nejrozsáhlejších studijních plánů. Během studia se připravují na podporu celkového osobnostního a sociálního rozvoje žáků, otevírání potencialit každého žáka, na naplňování šíře kognitivních, afektivních a psychomotorických cílů. Jejich studijní plány musí zahrnovat oborovědidaktickou prípravu na všechny vzdělávací oblasti vymezené Rámcovým vzdělávacím programem pro základní vzdělávání a určené pro 1. stupeň. Absolventi mají být zároveň připraveni na integraci učiva jako přirozeného zpưsobu poznávání světa žáky $v$ primárním vzdělávání. Kličové postavení mezi předměty, které budou budoucí učitelé pro primární školy, i z hlediska rozsahu, učit, nadále mají mateřský jazyk a matematika. Diskutováno je např́klad místo uměleckých výchov v kurikulu vzdělávání učitelů pro primární školy. Pro jejich přítomnost je třeba dále argumentovat, protože rozvíjejí v člověku tvořivost a nabízejí také vedle jazyka další prostředky vyjadřování a komunikace.

$\checkmark$ profesionalizačně zaměřeném vzdělávání zahrnují studijní plány teoretické předměty, ale také rozvinuté systémy reflektovaných praxí. Jsou koncipovány předměty, jejichž hlavním cílem je porozumění sobě, učitelské profesi i strategiím osobnostně sociálního a profesního rozvoje $v$ celoživotní perspektivě. Studenti multioborového studia mohou mít problém $\mathrm{s}$ tím, že maji obsáhnout značnou šíri současného vědění v souvislostech, zvlášt' pokud přijmou za své konstruktivistické přistupy $\mathrm{k}$ učení žáků. Reálně však nemají možnost se věnovat všem disciplínám tak do hloubky jako budoucí učitelé pro vyšší stupně vzdělávání. Tento problém je ve vzdělávacích programech učitelství pro primární školy částečně řešen volbou specializace či zaměření.

\subsection{Propojování teorie a praxe}

Klíčovou charakteristikou reflektivně zaměřeného vzdělávání učitelů je propojování teorie a praxe (Lukášová, 2015). K jeho naplňování jsou však nutné radikální změny nejen v cílech a vyučovaných obsazích, ale také ve výukových strategiích a celkové organizaci vzdělávání. Propojování teoretických a praktických předmětů tvoří vhodný prostor pro rozvoj a integraci pedagogicko-psychologických a oborovědidaktických znalostí a dovedností. Praxe iniciuje otázky a výzvy studentů učitelství, teoretické předměty dávají prostor $\mathrm{k}$ reflexi praktické zkušenosti včetně práce s novými poznatky, které vedou studenty učitelství k hlubšímu přemýšlení a porozumění žákovi, obsahům, zpưsobům pomoci žákům s různými vzdělávacími potřebami a také sobě jako budoucím učitelům.

Jeden z možných způsobů naplňování principu propojování teorie s praxí ve vzdělávání učitelů reprezentuje model reflektivně pojatého vzdělávání, zformulovaný $v$ zahraničí préedevším Korthagenem et al. (2011). Klíčovou kategorií v reflektivním př́stupu ke vzdělávání je reflexe. Reflexe usouvztažňuje zkušenost, minulou činnost 
20 studentů s profesními znalostmi a profesními vzdělávacími cíli (Tomková, 2018). Reflexe je v reflektivním př́stupu ke vzdělávání spojována především se systémy reflektovaných pedagogických praxí, které však musí být propojovány s teoretickými předměty. To vyžaduje spolupráci vysokoškolských učitelů a učitelů z praxe i budování široké sítě kvalitních škol dlouhodobě spolupracujících s fakultami připravujícími učitele (Spilková, 2015). Nutností je také dostatečný legitimní prostor na reflexi ve studijních plánech. Studenti se potřebují reflexi učit, také ve společenství se svými vzdělavateli.

\subsection{Nové formy pedagogické praxe}

V reflektivním přistupu ke vzdělávání učitelů má důležitou roli gradační systém pedagogických praxí, který umožňuje studentovi učitelství stávat se učitelem a postupně nabývat profesních kompetencí nutných pro úspěšný vstup do profese. Gradace může být $v$ jednotlivých programech vyjádřena různě, např. od prvotního celkového vhledu studentů do současné školy a výuky, přes zaměření na rozvoj pedagogicko-psychologických a oborovědidaktických profesních kompetencí, k závěrečné integraci poznatků a zkušeností a také učitelských rolí, včetně komplexního přebírání odpovědnosti za obsahy, procesy i výsledky učení žáků. Nejen v přípravě učitelů pro primární školy považujeme za dủležité, zvláště v kontextu principu společného vzdělávání žáků, pokud budoucí učitelé mohou dlouhodobě praktikovat v jedné třídě a být nablízko konkrétním žákům, hlouběji poznávat jejich potřeby, být přítomni jejich vývoji a pokrokům $v$ učení, vedle akcentu na obsahy, které mají být ve škole vyučovány, a na jejich didaktické zpracování. Vedle praxí oborových didaktik se $\checkmark$ programech učitelství pro primární školy proto rozvíjejí asistentské praxe, které vybavují studenty učitelství kompetencemi nutnými pro výuku v kontextu společného vzdělávání žáků. Asistentské praxe dovolují dobře reagovat také na individuální potřeby profesního rozvoje každého jednotlivého studenta učitelství. Přispívají $\mathrm{k}$ porozumění principu vnitřní diferenciace a individualizace výuky. Také v případě asistentských praxí je nezbytné, aby studenty přijímali kvalitní učitelé z praxe, jejichž profesní výbavou jsou též mentorské dovednosti.

Praktickou složku učitelské př́pravy nelze zužovat pouze na reflektované pedagogické praxe. Praktická příprava může mít i podobu mikrovyučování. Studenti učitelství mají rovněž reflektovat v seminárích to, jak se učí, protože učební postupy jsou také předmětem jejich př́pravy - princip izomorfismu (Tomková, 2015). Taktéž v závěrečných pracích studenti učitelství často zpracovávají akční výzkumy realizované na pedagogických praxích. Ve studiu je třeba integrovat všechny příležitosti, které nabízejí propojování teorie s praxí a přemýšlení o významu tohoto propojování pro učitelské vzdělávání. S proměnou vstupní výbavy současných studentů zvláště v kombinovaném studiu (bez vlastní praxe, s různou motivací k vykonávání učitelské profese) může docházet i k jinému problému. Tito studenti mají ostych ze sdílení zkušeností a reflexí praktické zkušenosti a z intenzivnějšího zařazování praktických 
aktivit do výuky. K podpoře výraznějšího setkávání těchto studentů s praxí jsou proto ověřovány další možnosti včetně společné práce s výukovými videi a videosituacemi.

\subsection{Nástroje podporující reflektivní pojetí vzdělávání}

Reflektivní pojetí pedagogické praxe, ale i celkového učitelského vzdělávání, vychází z předpokladu, že student učitelství se učí rozumět učitelské profesi a nárokům na ni. Porozumění očekávaným profesním činnostem učitele a jejich reflektování a sdílení má umožnit studentům učitelství více se angažovat ve svém profesním rozvoji, určovat si své rozvojové profesní cíle a reflektovat posuny v tomto profesním učení. V tomto ohledu v ČR stále trvá absence oficiálního učitelského standardu a vysokoškolská pracoviště si tvoří své materiály nebo využívají jiné dostupné dokumenty, např. Kompetentní učitel 21. století (2011) či Rámec profesních kvalit učitele (Tomková et al., 2012). Obecný popis profesních činností studentů učitelství s uvedením př́kladů indikátorů kvality koresponduje s multioborovostí profese učitele pro primární školy.

Odborníky jsou vyvíjeny také další konkrétní nástroje, které kvalitní reflexi studentů učitelství podporují a cíleně je vedou $\mathrm{k}$ tomu, aby se ke své praktické zkušenosti a procesům stávání se učiteli obraceli kriticky a aby při hledání alternativ řešení pracovali s novými poznatky (např. ALACT viz Korthagen et al., 2011; WANDA viz Spilková et al., 2015). Rolí vysokoškolského učitele je pomáhat studentům porozumět kritériím a indikátorům kvality práce studenta-budoucího učitele a také porozumět smyslu všech fází reflexe. V praxi se stává, že studenti mají tendenci $\checkmark$ reflexi vypustit právě fázi práce s novými informacemi a reflexi pak vyhodnocují jako zbytečnou, odvádějící je od př́mé práce se žáky ve školní tř́íě. Rizikem ve využívání reflektivních nástrojů zůstává nedostatečná hloubka reflektování didaktických situací v úzké souvislosti se specifickými oborovými a oborovědidaktickými znalostmi. Zde nelze než zdůraznit nutnou spolupráci nejen vysokoškolských učitelů a učitelů z praxe, ale též obecných didaktiků a oborových didaktiků na praxích i v reflektivních seminárích, ale také při zadávání, komentování a hodnocení písemných úkolů studentů nebo jejich závěrečných diplomových prací.

\subsection{Proměny hodnocení v reflektivním přistupu ke vzdělávání}

Reflektivní př́stup ke vzdělávání nutně proměňuje také zažité postupy hodnocení procesů a výsledků studia vysokoškolských studentů. $V$ reflektivním pojetí je akcent kladen na formativní hodnocení, podávání zpětné vazby, vrstevnické hodnocení a sebehodnocení studentů. Formativní hodnocení zapojuje studenty do procesů hodnocení. Cílem je autonomní hodnocení, dovednost studenta samostatně hodnotit své pokroky a výsledky vzhledem k očekávaným cílům, dovednost umět si stanovovat další cíle profesního rozvoje a nacházet cesty jejich naplňování. Tento nový důraz na formativní hodnocení v praxi vysokých škol naráží na zažité důrazy na sumativní hodnocení. Je logické, aby součástí závěrečného hodnocení studenta, který studoval 
22 v reflektivně pojatém vzdělávání, bylo také sebehodnocení opřené o důkazy znalostí, přemýšlení i praktických dovedností budoucího učitele. Profesionalizačně zaměřené vzdělávání se nemůže spokojit s úzce pojatým ověřováním znalostí studenta.

\subsection{Profesní portfolio}

Profesní portfolio je v reflektivním přístupu ke vzdělávání využíváno jako prostředek podpory profesního učení, reflexe a sebereflexe studentů učitelství, uvědomování si významu praktických zkušeností, teorií a jejich významů pro pedagogickou praxi, angažování se $v$ pedagogických inovacích. Výzkumy již prokázaly účinky práce s profesními portfolii na konstruování profesního vědění, na rozvoj metakognitivní, komunikativní a sociální kompetence studentů, na stimulování učitelů k reflexi a profesnímu rozvoji, $\mathrm{k}$ posílení autentického sumativního hodnocení (Bélair \& Van Nieuwenhoven, 2010; Lukášová et al., 2014; Shulman, 1998; Tomková, 2018; Zeichner \& Wray, 2001). Jsou rovněž odhalena rizika a limity práce s profesními portfolii, např. nebezpečí exhibice, trivializace, nízká reprezentativnost obsahu, časová náročnost, nebezpečí konfliktních koncepcí portfolií, riziko pnutí mezi funkcemi (Píšová, 2007; Smith \& Tillema, 2006; Spilková, 2007; Tomková, 2018). Je konstatováno, že ve vzdělávání učitelů jsou portfolia využivána ve dvou základních funkcích: na podporu učení a k sumativnímu autentickému hodnocení.

V souvislosti s rozvojem reflektivního přístupu ke vzdělávání učitelů pro primární školy v ČR jsou také vyvíjena profesní portfolia v konkrétních koncepčních záměrech. Využivání těchto portfolií je dokumentováno a výzkumně zpracováváno (kupř. Lukášová et al., 2014; Píšová, 2007; Tomková, 2018). Profesní portfolio je v ČR rozpracováváno zvláště v souvislosti s diskusemi o koncepci státních závěrečných zkoušek. Zatím nedostatečně využivanou funkcí portfolií je funkce podpory profesního učení a rozvoje reflektivity studentů $v$ průběhu studia. Jednotlivé koncepční záměry mohou akcentovat při práci s portfolii práci s materiály, které student tvořil v průběhu svého studia (Pedagogická fakulta Univerzity Karlovy), nebo tvorbu nového produktu syntetizujícího dosavadní učení studenta učitelství (Pedagogická fakulta Ostravské univerzity). Prosazuje se také koncepce portfolií založených na dokládání úkolů, která však znovu zdůrazňuje roli vzdělavatelů nad možnou iniciativou a pedagogickou tvořivostí studentů učitelství. V oboru učitelství pro primární školy je třeba nadále ověřovat možnosti využíání profesního portfolia pro integraci obsahů a pokroků profesního učení studentů. $\mathrm{K}$ tomu je však potřeba ve studijních programech vytvořit jasné průběžné př́ležitosti $k$ tvorbě, sdílení, prezentování a obhajování portfolií, ve spolupráci obecných a oborovědidaktických pedagogů, učitelů z praxe a samožrejmě studentů. 


\section{Shrnutí - Možnosti a meze profesionalizačních tendencí $v$ přípravě učitelů}

Univerzitní vzdělávání učitelů pro primární školy v České republice lze charakterizovat jako profesionalizačně zaměřené studium, které připravuje své absolventy na kvalitní zvládání profese a současně je dobrým základem pro celoživotní profesní růst. Přesto je důležité, aby další proměny přípravného vzdělávání učitelů pro primární školy byly i nadále předmětem odborných diskusí a pedagogického výzkumu. Tyto debaty by měly navazovat na výzkumná data a reflektované zkušenosti z rozsáhlých inovací učitelského vzdělávání na jednotlivých pedagogických fakultách v uplynulých pětadvaceti letech.

Od poloviny devadesátých let byla v rámci řady výzkumných projektů ověřována účinnost inovativních př́stupů k obsahu i procesům vzdělávání budoucích učitelů primárních škol. Přehled o vývoji studia tohoto oboru na všech pedagogických fakultách v ČR i SR po roce 1989 do roku 2010 přináší monografie Spilkové a Hejlové (2010). Významné výsledky přinesly také akční výzkumy v rámci sedmiletého výzkumného projektu Učitelská profese $v$ měnících se požadavcích na vzdělávání (2007-2013) pod vedením $\mathrm{V}$. Spilkové, na jehož řešení se podíleli odborníci z více fakult. Na většině fakult se potvrdilo, že posílení profesionalizace studia, ukotvení v rozvíjející se primární pedagogice, posílení důrazu na osobnostní rozvoj studenta, na reflektivní pojetí, které akcentuje systematickou teoretickou reflexi praktických zkušeností v roli učitele jako klíčový faktor profesního růstu, vedou k vyšší kvalitě (např. Spilková, 2015; Spilková \& Hejlová, 2010). Ukázaly se však také rezervy a limity některých přístupů, jejichž zmírnění, či odstranění, je stále ještě výzvou. Ve hře je otázka, co je vůbec $v$ současném systému a v daných kontextech reálné.

Co se týče důrazu na profesionalizaci studia, jejímž jádrem jsou profesní znalosti a dovednosti $v$ relevantních oborech, pak jsou stále rezervy ve vymezení poznatkové báze učitelství, v konkretizaci tzv. nepominutelných obsahů. To znamená podrobit klíčové obory pro profesionalizačně orientované studium kritické analýze, provést jejich revizi pod zorným úhlem toho, co má smysl zprostředkovávat, co je skutečně podstatné $z$ hlediska současných nároků na učitelskou profesi. Jedním z nejobtižnějších úkolů je nalezení optimální proporce mezi jednotlivými oblastmi profesních znalostí (viz sedm oblastí profesních znalostí, které jsou základem pro tvorbu kurikula učitelské př́pravy, definovaných v předcházejícím textu). Přestože je nyní kladen důraz kromě pedagogicko-psychologických znalostí na didaktickou znalost obsahu, oborové znalosti mají v kurikulu také své důležité místo. Obecněji řečeno - z hlediska komplexu profesních znalostí - bude otázka citlivého vyvážení mezi na žáka, na osobnostně rozvíjející pojetí vzdělávání na jedné straně (Helus, 2012; Kratochvílová et al., 2015; Lukášová, 2015; Spilková et al., 2004; Spilková \& Hejlová, 2010; Tomková, 2016, 2018) a obsahově zaměřeným přístupem na straně druhé (např. Janík, 2005; Janík et al., 2013) i nadále předmětem zájmu teorie, výzkumu i praxe vzdělávání učitelů primárních škol. 
Vzhledem k šiři profilu učitele primární školy a mnohokrát zmiňované multidisciplinaritě studia jsou stále velké rezervy $\mathrm{v}$ integrativně pojatém obsahu studia (Spilková, 2015; Tomková, 2016). Přes dosavadní snahy jsou studijní programy stále do značné míry fragmentarizované do jednotlivých oborů a kurzů. Za experimentální ověření by stála možnost strukturovat kurikulum učitelské př́pravy nikoli podle vědních disciplín, ale tematicky. Zde se lze inspirovat mimo jiné v modelu tzv. school based teacher education, který se v některých zemích výrazněji prosazuje, zejména v Nizozemsku, Belgii, Anglii, v jisté modifikaci i ve Finsku (Bendl et al., 2011; Grimmett \& Erickson, 1988; Hargreaves, 2000; Spilková et al., 2010, 2015). Tento model je založen na integrovaném studijním programu, $v$ němž jsou propojeny poznatky $\mathrm{z}$ různých akademických disciplín $\mathrm{v}$ rámci vybraných témat a současně jsou $\mathrm{v}$ těsné vazbě se získáváním praktických zkušeností v různých formách průběžné reflektované praxe.

Důležitou podmínkou pro kvalitní fungování tohoto modelu je úzká spolupráce fakult připravujících učitele a škol, a zejména součinnost vzdělavatelů učitelů a spolupracujících učitelů/mentorů jako facilitátorů profesního rozvoje studentů učitelství. Vzdělavatelé učitelů a mentoři tvoří jeden tým, který má společnou odpovědnost za plánování, realizaci a evaluaci kurikula učitelského vzdělávání. Vytváření dlouhodobě spolupracující profesní komunity (studenti, učitelé a vzdělavatelé učitelů), spolupracujícího učebního prostředí (collaborative learning enviroment), založeného na kolegiální podpoře a sdílení profesních znalostí a zkušeností, je $v$ tomto modelu chápáno jako jeden z kličcvých nástrojů nejen pro podporu profesního růstu studentů učitelství, ale i jako prostředek celoživotního profesního rozvoje ostatních aktérů $v$ učíci se komunitě. Podpora kultury kolegiálního profesního učení (culture of collegial professional learning), do niž jsou zahrnuti i výzkumníci, je považována za prioritu v úsilí o zvyšování kvality učitelů ve Finsku (Spilková et al., 2015).

Podobný př́stup $\mathrm{k}$ posílení integrace různých dimenzí studia učitelství lze sledovat také $v$ zámoří, zejména $v$ USA, $v$ koncepci tzv. klinicky zaměřené př́pravy budoucích učitelů (clinically based teacher preparation), v níz jsou klinické praxe a v jejím rámci získávané klinické zkušenosti studentů centrem a jádrem pro integraci teorie a praxe, pro integraci profesních znalostí (at' už oborových, oborovědidaktických, pedagogicko-psychologických aj.) a dovedností (Spilková et al., 2015). Záměrem je integrovat klinickou praxi do každé oblasti učitelské př́pravy, aby klinické zkušenosti byly východiskem a základem pro veškerou (i akademicky orientovanou) výuku budoucích učitelů (Transforming teacher education through clinical practice: A national strategy to prepare effective teachers. Report of the Blue Ribbon Panel on clinical preparation and partnerships for improved student learning, 2010).

$\checkmark$ obou uvedených modelech, a obecněji řečeno i $v$ dalších profesionalizačně zaměřených modelech studia (např. realistický př́stup v učitelském vzdělávání Korthagen et al., 2011), jsou kladeny nové, zcela specifické nároky na vzdělavatele učitelů. $V$ této souvislosti se upozorňuje na potřebu nové generace vzdělavatelů učitelů. Jednou z kličových podmínek fungování uvedených modelů je systematická př́prava vzdělavatelů učitelů a mentorů ze škol na nové role, na poskytování 
kompetentní zpětné vazby a celkové podpory studentům v procesech setkávání se s reálnými podobami učitelské profese. Jsou pro ně vytvářeny specifické vzdělávací kurzy a výcviky v supervizích a mentorských dovednostech. $V$ českém kontextu lze považovat nepřipravenost mnoha současných vzdělavatelů učitelů na tyto nové role za závažný limit pro kvalitní realizaci profesionalizačních modelů v širším měřítku. Obdobné rezervy lze sledovat také $v$ připravenosti učitelů z praxe na role mentorů, kvalitních průvodců a facilitátorů v profesním rozvoji studentů.

Profesionalizačně zaměřené modely studia vyžadují také budování sítě univerzitních, klinických, partnerských škol, které bývají přirovnávány k fakultním nemocnicím a jejich roli ve vzdělávání budoucích lékařů. Platí obecněji, že v oborech, $\checkmark$ nichž je za klíčovou považována integrace teorie a řízené, reflektované praxe pod supervizí, je nutnou podmínkou existence klinického pracoviště. Má-li mít toto pracoviště tak zásadní roli, musí splňovat vymezené parametry a mít legislativní ukotvení.

V českém prostředí zatím nejsou vytvořeny podmínky - legislativní, materiální, personální, organizační -, které by systematicky podporovaly profesionalizaci př́pravy učitelů, tedy mimo jiné vznik klinických pracovišt', jako je tomu u lékařů. Přes nepř́iznivé podmínky bylo $v$ posledních patnácti letech $v$ České republice realizováno a výzkumně ověřováno několik profesionalizačně zaměřených modelů s důrazem na gradovaný systém reflektivní, klinické praxe $v$ př́pravě učitelů. Opakovaně byl prokázán výrazný pozitivní vliv na kvalitu profesního rozvoje studentů učitelství v průběhu i závěru studia (např. klinický rok - Píšová, 2005; Píšová \& Černá 2002, 2006; klinické dny - Spilková, 2004; Tomková, 2018; klinický semestr - Bendl et al., 2011; dále Lukášová et al., 2014; Lukášová-Kantorková, 2002). Ukázaly se také limity realizace $v$ masovém měřítku, které nejsou zevnitř systému řešitelné, ale vyžadují naopak vytvoření komplexu podmínek zejména ze strany vzdělávací politiky a decizní sféry.

Klíčovou výzvou pro profesionalizačně pojaté modely př́pravy učitelů je snaha vyvážit tzv. akademické pojetí a tzv. kompetenční pojetí prípravy učitelů. Trend k výraznější profesionalizaci v kontextu univerzitního vzdělávání v určitém slova smyslu zvyšuje napětí mezi tradičně chápaným akademickým pojetím př́ípravy učitelů, které klade důraz na odborné znalosti v daných oborech, nesleduje cíleně praktické využití výsledků studia ve vztahu ke kontextům školní reality (např. Urbánek, 2016), a kompetenčním pojetím př́pravy, jež klade důraz na získávání specifických profesních kompetencí vázaných na profesní standard, jehož hlavním cílem je příprava na kvalitní výkon profese.

Domníváme se, že takto polarizované pojetí už není v současném kontextu teorie, výzkumu i praxe učitelského vzdělávání plně opodstatněné a funkční. Výše popsané zahraniční i domácí modely profesionalizačně orientovaného studia učitelství s důrazem na reflektivní, realistické, klinické př́stupy k osvojování profese jsou podle našeho názoru dokladem, že mají potenciál spojovat přednosti obou př́istupů a snaží se eliminovat rizika, která při absolutizaci a přeceňování některých prvků těchto modelů hrozí. Důraz na hledání rovnováhy mezi akademickým a kompetenčním 
26 př́stupem vyjadřuje také prosazující se pojetí učitelství jako akademicky založené klinické profese (academically taught clinical practice profession), která vyžaduje jak zprostředkování poznatkové základny v tradičním akademickém pojetí, tak klinickou praxi v „klinických“ školách (v klinickém prostředí), jejímž jádrem je výuková činnost studentů učitelství (Alter \& Coggshall, 2009; Černá, Píšová, \& Vlčková, 2017).

Profesionalizační pojetí se tedy snaží překonat jak jednostranný důraz na teoretické vzdělávání v izolovaných disciplínách bez vztahu ke konkrétním kontextům školní reality a k profesním zkušenostem studentů učitelství, tak i přeceňování důrazu na nácvik profesních dovedností, které by mohlo vést $\mathrm{k}$ řemeslnému a prakticistnímu pojetí prípravy na profesi bez potřebného teoretického zázemí při budování profesních znalostí (Spilková et al., 2008).

\section{Literatura}

Alter, J., \& Coggshall, J. G. (2009). Teaching as a clinical practice profession: Implications for teacher preparation and state policy. New York: Comprehensive Center and the National Comprehensive Center on Teacher Quality.

Barr, R. J., \& Tagg, J. (1995). From teaching to learning: A new paradigm for understanding education. Change, 27(6), 12-25.

Bélair, L. M. \& Van Nieuwenhoven, C. (2010). Le portfolio, un outil de consignation au d'évaluation authentique? In L. Paquay, C. Van Nieuwenhoven, \& P. Wouters (Eds.), L'évaluation, levier du dévéloppement professionnel? (s. 162-175). Bruxelles: Groupe de Boeck.

Bendl, S., et al. (2011). Klinická škola: místo pro výzkum a praktickou prípravu budoucích učitelů. Praha: PedF UK.

Bravená, N. (2012). Transcendování a nové podněty pro edukaci obratu. In Z. Helus, N. Bravená, \& M. Franclová, Perspektivy učitelství (s. 49-92). Praha: PedF UK.

Černá, M., Píšová, M., \& Vlčková, K. (2017). Vliv klinické zkušenosti na profesní rozvoj studentů učitelství. Studia paedagogica, 22(3), 44-68.

Dvořák, D., Starý, K., Urbánek, P, Chvál, M., \& Walterová, E. (2010). Česká základní škola. Vícečetná príípadová studie. Praha: Karolinum.

Funda, O. A. (1995). Učitelovo sebevzdělávání. Pedagogika, 45(1), 2.

Gavora, P. (2008). Profesijná zdatnost’ vnímaná učitelom (self-efficacy). In A. Wiegerová (Ed.), Premeny školy a učitelskej profesie (s. 17-26). Bratislava: Občianskej združenie Výchova-Veda-Vzdelávanie-Výskum.

Grimmett, P. P., \& Erickson, G. L. (1988). Reflection in teacher education. New York: Teacher College Press.

Hargreaves, A. (2000). Four ages of professionalism and professional learning, Teachers and Teaching: Theory and Practice, 6(2), 151-182.

Havlínová, H. (2016). Proměny pohledu na výuku čtení v české škole prizmatem výzkumů: od nácviku techniky čtení k rozvoji čtenářské gramotnosti. Orbis Scholae, 10(2), 145-157.

Hejlová, H. (2010). Vzdělávání v právech dítěte výzva pro učitele. Praha: PedF UK.

Hejlová, H., Opravilová, E., Bravená, N., \& Uhlířová, J. (2013). Nahližení do světa dětí. Praha: PedF UK.

Helus, Z. (1999). Ohrožení a možnosti vývoje dítěte v naší době. In V. Spilková \& H. Hejlová (Eds.), Univerzitní vzdělávání učitelů primární školy na přelomu století (s. 13-22). Praha: PedF UK.

Helus, Z. (2001). Alternativní pohled na kompetence učitelů. In E. Walterová (Ed.), Učitelé jako profesní skupina, jejich vzdělávání a podpůrný systém, sv. 2 (s. 44-49). Praha: PedF UK. 
Helus, Z. (2009). Dítě v osobnostním pojetí. Praha: Portál.

Helus, Z. (2012). Učitel - vůdčí aktér osobnostně rozvíjející výuky. In Z. Helus, N. Bravená, \& M. Franclová, Perspektivy učitelství (s. 7-48). Praha: PedF UK.

Hoidn, S. (2016, únor). Vytváření prostředí orientovaného na studenta ve vysokoškolském vzdělávání. Příspěvek prezentovaný na odborném semináři ÚVRV na PedF UK, Praha.

Horká, H., Filová, H., Janík, T., \& Kratochvílová, J. (2015). Studie ze školní pedagogiky. Brno: MU.

Horká, H., \& Kratochvílová, J. (2008). Na cestě k profesní autonomii aneb Jak je koncipována pedagogická složka profesionální přípravy učitelů 1. stupně ZŠ na Pedagogické fakultě MU. In Současnost a budoucnost učitelského vzdělávání (s. 85-91). Ostrava: Ostravská Univerzita v Ostravě, Pedagogická fakulta, 2008.

Hošpesová, A. (2016). Badatelsky orientovaná výuka matematiky na 1. stupni základního vzdělávání. Orbis Scholae, 10(2), 117-130.

Hustler, D., \& Intyre, D. (1996). Developing competent teachers. London: David Fulton Publishers.

Janík, T. (2005). Znalost jako klíčová kategorie učitelského vzdělávání. Brno: Paido.

Janík, T., Slavík, J., Mužík, V., Trna, J., Janko, T., Lokajičková, V., ... Zlatníček, P. (2013). Kvalita (ve) vzdělávání: obsahově zaměřený přistup ke zkoumání a zlepšování výuky. Brno: MU.

Kelchtermans, G. \& \& Ballet, K. (2002). The micropolitics of teacher induction. A narrative-biographical study on teacher socialisation. Teaching and Teacher Education, 18(1), 105-120.

Kolláriková, Z., \& Pupala, B. (2001). Předškolní a primární pedagogika-predškolská a elementárna pedagogika. Praha: Portál.

Kompetentní učitel 21. století. Mezinárodní profesní rámec kvality ISSA. (2011). Praha: Step by Step ČR.

Korthagen, F. A. J. (2004). In search of the essence of good teacher: Toward a more holistic approach in teacher education. Teacher and Teacher Education, 20(1), 77-97.

Korthagen, F., Kessels, J., Koster, B., Lagerwerf, B., \& Wubbels, T. (2011). Jak spojit praxi s teorií: Didaktika realistického vzdělávání učitelů. Brno: Paido.

Kořínek, M. (1981). Zdokonalování prípravy a dalšího vzdělávání učitelů prvního stupně základní školy. Praha: UK.

Kot’a, J. (1998). Učitelské povolání z pohledu sociálních věd. Praha: PedF UK.

Kot'a, J. (2010). Vybrané problémy profesionalizace učitelů v postmoderní době. In H. Krykorková \& R. Váňová, et al., Učitel v současné škole (s. 57-76). Praha: FF UK.

Kratochvílová, J., Horká, H., \& Chaloupková, L. (2015). Rozvoj osobnostních a profesních kompetencí učitele 1. stupně základní školy. Brno: MU.-

Lukášová, H. (2003). Učitelská profese v primárním vzdělávání a pedagogická příprava učitelů (teorie, výzkum, praxe). Ostrava: PdF OU.

Lukášová, H. (2010). Kvalita života a dětí a didaktika. Praha: Portál.

Lukášová, H. (2015). Učitelské sebepojetí a jeho zkoumání. Zlín: FHS UTB.

Lukášová, H., Svatoš, T., \& Majerčíková, J. (2014). Studentské portfolio jako výzkumný prostředek poznání cesty $k$ učitelství. Příspěvek $k$ autoregulaci profesního učení a seberozvoje. Zlín: FHS UTB.

Lukášová-Kantorková, H. (Ed.). (2002). Profesionalizace vzdělávání učitelů a vychovatelů. Ostrava: PdF OU.

Lukavská, E. (2003). Pozor, děti! Dobrá Voda: Vydavatelství a nakladatelství Aleš Čeněk.

Mareš, J., \& Beneš, J. (2013). Proměny studia učitelství na pedagogických fakultách v ČR $v$ letech 2000-2012 dané Boloňským procesem. Pedagogika, 63(4), 427-459.

Nelešovská, A., et al. (1995). Příprava učitelů primárního vzdělávání. Závěrečná zpráva grantového úkolu FRVŠ. Olomouc: PdF UP.

Nezvalová, D. (1994). Reflexe v pregraduální přípravě učitele. Pedagogika, 44(3), 241-245.

Perrenoud, P. (2001). Développer la pratique réflexive dans le métier d'enseignant. Professionnalisation et raison pédagogique. Paris: ESF.

Píšová, M. (2005). Klinický rok: procesy profesního rozvoje studentů učitelství a jejich podpora. Pardubice: UP. 
28 Píšová, M. (Ed.). (2007). Portfolio v profesní př́ipravě učitele. Pardubice: UP.

Píšová, M. , \& Černá, M. (2002). Klinický rok. In V. Švec (Ed.), Profesní rưst učitele (s. 187-192). Brno: Konvoj.

Píšová, M., \& Černá, M. (2006). Pro mentory projektu Klinický rok. Pardubice: UP.

Píšová, M., Najvar, P., Janík, T., Hanušová, S., Kostková, K., Janíková, V., ... Zerzová, J. (2011). Teorie a výzkum expertnosti v učitelské profesi. Brno: MU.

Pit’ha, P., \& Helus, Z. (1993). Návrh pojetí obecné školy. Praha: Portál.

Pollard, A. (2001). Reflective teaching. London: Cassel.

Pravdová, B. (2014). Já jako učitel: profesní sebepojetí studenta učitelství. Brno: MU.

Rabušicová, M., \& Pol, M. (1996). Vztahy školy a rodiny dnes: Hledání cest k partnerství. Pedagogika, 46(2), 105-116.

Rámcová koncepce př́pravného vzdělávání učitelů primárních škol v ČR. (2017). In I. Stuchlíková \& T. Janík, Rámcová koncepce př́pravy učitelů základních a středních škol aneb O hledání a nacházení konsensu mezi aktéry. Dostupné z https://www.researchgate.net /publication/319457497_Ramcova_koncepce_pripravy_ucitelu_zakladnich_a_strednich skol_aneb_o_hledani_a_nachazeni_konsensu_mezi_aktery

Rámcové požadavky na studijní programy, jejichž absolvováním se získává odborná kvalifikace $k$ výkonu regulovaných povolání pedagogických pracovníkü. (2017). MŠMT. Dostupné z http://www.msmt.cz/vzdelavani/dalsi-vzdelavani/ramcove-pozadavky-na-studijniprogramy-jejichz-absolvovanim

Shulman, L. S. (1998). Teacher portfolios: A theoretical activity. In N. Lyons (Ed.), With portfolio in hand. Validating the new teacher professionalism (s. 23-37). New York: Teacher College Press.

Shulman, L. S. (1987). Knowledge and teaching: Foundations of the new reform. Harvard Educational Review, 57(1), 1-22.

Schön, D. A. (1983). The reflective practitioner: How professionals think in action. London: Temple Smith.

Slavík, J. (2001). La pratique réflexive dans la formation des enseignants d'arts plastiques: phénomène pédagogique dans un contexte politique (expérience tchèque). Recherche et formation: pour les professions de l'éducation, 10(36), 113-129.

Slavík, J., Stará, J., Uličná, K., \& Najvar, P. (2017). Didaktické kazuistiky v oborech školního vzdělávání. Brno: MU.

Smith, K., \& Tillema, H. (2006). Portfolios for professional development: A research journey. New York: Nova Science Publishers.

Spilková, V. (1997). Proměny primární školy a vzdělávání učitelů v historicko-srovnávací perspektivě. Praha: PedF UK.

Spilková, V. (1998). Současné změny v pojetí učitelské profese (s důrazem na učitelství primární školy). In R. Havlík, et al., Učitelské povolání z pohledu sociálních věd (s. 60-77). Praha: PF UK.

Spilková, V. (2007). Význam portfolia pro profesní rozvoj studentů učitelství. In M. Píšová (Ed.), Portfolio v profesní přípravě učitele (s. 7-20). Pardubice: Univerzita Pardubice.

Spilková, V. (2011). Development of student teachers ‘ professional identity through constructivist approaches and self-reflective techniques. Orbis scholae, 5(2), 117-138.

Spilková, V. (2015). Integrativní přístup v primárním vzdělávání a v přípravě učitelů. In Kolektiv autorů, Integrativní přistup v primárním vzdělávání. Liberec: TUL.

Spilková, V. (2016). Přístupy české vzdělávací politiky po roce 1989: Deprofesionalizace učitelství a učitelského vzdělávání? Pedagogika, 66(4), 368-385.

Spilková, V., et al. (2004). Současné proměny vzdělávání učitelů. Brno: Paido.

Spilková, V., et al. (2005). Proměny primárního vzdělávání v ČR. Praha: Portál.

Spilková, V., \& Hejlová, H. (Eds.). (1999). Univerzitní vzdělávání učitelů primární školy na přelomu století. Praha: PedF UK.

Spilková, V., \& Hejlová, H. (Eds.). (2010). Př́prava učitelů pro primární a preprimární vzdělávání v Česku a na Slovensku. Vývoj po roce 1989 a perspektivy. Praha: PedF UK.

Spilková, V., \& Tomková, A., et al. (2010). Kvalita učitele a profesní standard. Praha: PedF UK. 
Spilková, V., Tomková, A., Mazáčová, N., \& Kargerová, J., et al. (2015). Klinická škola a její role ve vzdělávání učitelü. Praha: Retida.

Spilková, V., \& Vašutová, J., et al. (2008). Učitelská profese v měnících se požadavcích na vzdělávání. Praha: PedF UK.

Štech, S. (2004a). Pojetí vztahu školy a rodiny. Pedagogika, 54(4), 372-373.

Štech, S. (2004b). Psycho-didaktika jako obrat k tématu účinného vyučování. Komentář na okraj Kansanenovy úvahy Didaktika a její vztah k pedagogické psychologii. Pedagogika, 54(1), 58-63.

Štech, S., \& Viktorová, I. (2001). Vztahy rodiny a školy - hledání dialogu. In Z. Kolláriková \& B. Pupala, Předškolní a primární pedagogika - predškolská a elementárna pedagogika (s. 57-94). Praha: Portál.

Švec, V. (1999). Pedagogická příprava budoucích učitelů: Problémy a inspirace. Brno: Paido.

Švec, V. (Ed.). (2000). Monitorování a rozvoj pedagogických dovedností. Brno: Paido.

Švec, V. (2005). Pedagogické znalosti: teorie a praxe. Praha: ASPI Publishing.

Švec, V. (2009). Př́pravné vzdělávání učitelů. In J. Průcha (Ed.), Pedagogická encyklopedie (s. 408-412). Praha: Portál.

Švec, V., et al. (2014). Znalostní báze učitelství. Brno: MU.

Švrčková, M. (2011). Kvalita počáteční čtenářské gramotnosti: Výzkumná analýza a popis soudobého stavu. Ostrava: PdF OU.

Tomková, A. (2015). Princip izomorfismu v učitelské př́ípravě. Pedagogika, 65(1), 75-81.

Tomková, A. (2016). Př́prava učitelů a hodnocení její kvality v Belgii. Praha: PedF UK.

Tomková, A. (2018). Portfolio v perspektivě reflektivně pojatého vzdělávání učitelů. Praha: PedF UK.

Tomková, A., Spilková, V., Pí̌́ová, M., Mazáčová, N., Krčmářová, T., Kostková, K., \& Kargerová, J. (2012). Rámec profesních kvalit učitele. Hodnoticí a sebehodnoticí arch. Praha: Národní ústav pro vzdělávání.

Tuček, A. (1994). Poslání a osobnost učitele. In V. Spilková, H. Vyskočilová, A. Tuček, \& J. Uhlířová, K současnému pojetí didaktiky základní školy (s. 26-32). Praha: UK.

Urbánek, P. (2016). Akademický či kompetenční koncept vzdělávání učitelů. Nutná bipolarita? In M. Strouhal (Ed.), Učit se být učitelem. K vybraným problémům učitelského vzdělávání (s. 44-69). Praha: Karolinum.

Vašutová, J. (2004). Profese učitele v českém vzdělávacím kontextu. Brno: Paido.

Váňová, R. (1995). Několik pohledů do historie učitelského vzdělávání u nás. Pedagogika, 45(1), 4-10.

Weinert, F. E. (2001). Concept of competence: A conceptual clarification. In D. S. Rychen, $\&$ L. H. Salganik (Eds.), Defining and selecting key competencies (s. 45-65). Seattle, WA: Hogrefe and Huber Publishers.

Wildová, R. (2005). Rozvíjení počáteční čtenářské gramotnosti. Praha: PedF UK.

Zeichner, K., \& Wray, S. (2001). The teaching portfolio in U. S. teacher education programs: What we know and what we need to know. Teaching and Teacher Education, 17(5), 613-621.

doc. PhDr. Anna Tomková, Ph.D. katedra preprimární a primární pedagogiky Pedagogická fakulta, Univerzita Karlova Magdalény Rettigové 4, 11639 Praha 1 anna.tomkova@pedf.cuni.cz

prof. PhDr. Vladimíra Spilková, CSc. katedra anglistiky a amerikanistiky Filozofická fakulta, Univerzita Pardubice Studentská 84, 53210 Pardubice vladimira.spilkova@email.cz 